\title{
PERAN PENDIDIKAN KEWARGANEGARAAN DALAM MEMBANGUN MASYARAKAT BERJIWA NASIONAL
}

Resfira

SMAN 1 Batang Anai

resfira.m.pd@gmail.com

\begin{abstract}
Abstrak
Saat ini bangsa Indonesia dihadapkan pada suatu masa dimana bangsa ini mengalami perkembangan dan perubahan yang sangat pesat. Perkembangan ini dikhawatirkan akan melunturkan nilai-nilai Pancasila dalam diri setiap warga Negara Indonsia. Oleh karena itu, mata pelajaran PKn sangat diperlukan. Dengan memunculkan kembali nilai-nilai utama dalam PKn diharapkan dapat membangun jiwa nasionalisme yang dilandasi oleh nilai ketuhanan, kemanusiaan, persatuan, kerakyatan, keadilan sosial, kompetisi, menghormati orang lain, kemerdekaan dan perdamaian. Nilai-nilai dasar ini penting untuk dikembangkan dalam rangka mengembangkan semangat dan jiwa nasionalime agar dapat berperan secara efektif dalam kancah global tanpa meninggalkan jati diri sebagai bangsa Indonesia yang memiliki Pancasila sebagai falsafah dalam kehidupan berbangsa dan bernegara.
\end{abstract}

Keywords: PKn, Masyarakat, Jiwa Nasional.

\section{PENDAHULUAN}

Indonesia sebagai bangsa yang telah merdeka mempunyai jati diri yang sangat luar biasa, yaitu Pancasila yang berperan sebagai idiologi, pandangan hidup sekaligus dasar negara. Ideologi Pancasila menyeimbangkan kehidupan individual dengan kehidupan social.

Pendidikan Kewarganegaraan (selanjutnya disebut dengan PKn) merupakan sebuah mata pelajaran yang juga mengajarkan mengenai ideology Pancasila. Mata pelajaran ini bertujuan salah satunya untuk meyakinkan kepada semua pihak, khususnya WNI, bahwa Indonesia mempunyai jati diri yang harus diaktualisasikan di tengah-tengah kehidupan masyarakat internasional. Indonesia mempunyai falsafah Pancasila, demokrasi Pancasila, berpegang teguh pada upaya menegakkan kedaulatan rakyat bukan kedaulatan individu. Dengan keyakinan itu, makan setiap WNI tidak mudah silau dan terpengaruh oleh falsafah, demokrasi dan kedaulatan yang dianut oleh bangsa lain kemudian menirunya. 
Lebih lanjut, PKn juga merupakan mata pelajaran yang bertugas bagaimana membentuk warga negara yang baik (how to be a good citizen). Warga negara yang baik adalah warga negara yang sadar akan hak dan kewajibannya. Dengan kesadaran akan hak dan kewajibannya maka seorang warga negara diharapkan menjadi kritis, partisipatif dan bertanggung jawab. Ukuran warga negara yang baik tentunya sangat dipengaruhi oleh ideologi nasional masing-masing negara. Bagi bangsa Indonesia ideologi Pancasila merupakan acuan dalam membina warga negara yang baik. Pendidikan Pancasila dan Kewarganegaraan (PPKn) sebagai PKn versi Indonesia memiliki fungsi memberdayakan warga negara dalam kehidupan berbangsa dan bernegara yang sejalan dengan Pancasila.

Dalam rangka mengaktualisasikan jati diri Indonesia, maka WNI perlu meneladani perilaku baik pendahulu bangsa dalam menemukan dan mengaktualisasikan jati diri Indonesia. Keberanian untuk tidak mengekor pada bangsa dan negara asing, merupakan sikap dan prilaku orang yang yakin mampu bersaing dengan bangsa dan negara lain. Ini berearti apa yang diciptakan mempunyai kualitas yang dapat sejajar dengan penemuan dan ciptaaan bangsa dan negara lain. Dengan demikian jati diri menjadikan kemandirian bagi dirinya sendiri. Untuk mewujudkan hal itu, maka diperlukan suatu langkah revitalisasi peran PKn dalam membangun jiwa nasionalisme warga Negara.

\section{KAJIAN TEORI}

\section{Pendidikan Kewarganegaraan}

Secara bahasa, istilah civic education oleh sebagian pakar diterjemahkan ke dalam bahasa Indonesia menjadi Pendidikan Kewargaan dan Pendidikan Kewarganegaraan. Kerr (Winataputra dan Budimansyah, 2012) mengemukakan bahwa Citizenship education or civics education didefinisikan sebagai berikut: Citizenship or civics education is construed broadly to encompass the preparation of young people for their roles and responsibilities as citizens and, in particular, the role of education (trough schooling, teaching, and learning) in that preparatory process. Maksud dari pendapat Kerr ini bahwa PKn secara luas mencakup proses penyiapan generasi muda untuk mengambil peran dan tanggung jawabnya sebagai warga negara. Sedangkan secara khusus, peran pendidikan termasuk di dalamnya persekolahan, pengajaran dan belajar, dalam proses penyiapan warga negara tersebut.

Cogan (1999) mengartikan civic education sebagai "the foundational course work in school designed to prepare young citizens for an active role in their communities in their adult lives", maksudnya adalah suatu mata pelajaran dasar di sekolah yang dirancang untuk mempersiapkan warga negara 
muda agar kelak setelah dewasa dapat berperan aktif dalam masyarakatnya.

Dengan demikian dapat dikatakan bahwa PKn atau civic education adalah program pendidikan/pembelajaran yang secara programatikprosedural berupaya memanusiakan (humanizing) dan membudayakan (civilizing) serta memberdayakan (empowering) manusia dalam hal ini peserta didik, diri dan kehidupannya menjadi warga negara yang baik sebagaimana tuntutan keharusan/yuridis konstitusional bangsa/negara yang bersangkutan (Djahiri, 2006).

Dari pemaparan di atas maka kita dapat menyimpulkan bahwa dilahirkannya PKn dimaksudkan sebagai perisai bagi suatu bangsa untuk menjaga hal-hal buruk atau negatif yang bisa merusak bangsa itu sendiri. Kemudian bagi bangsa Indonesia lahirnya PKn dimaksudkan sebagai wahana untuk membentuk warganegara yang cerdas terampil dan berkarakter yang setia kepada bangsa dan Negara Indonesai dengan merefleksikan dirinya dalam kebiasaan berfikir dan bertindak sesuai amanat Pancasila dan UUD 1945 serta tetap menjaga bangsa ini walaupun terdapat gempuran dari luar tetapi gempuran tersebut tetap ditangkal dengan nilai moral yang ada pada PKn itu sendiri.

\section{Nasionalisme}

Nation berasal dari bahasa Latin natio, yang dikembangkan dari kata nascor (saya dilahirkan), maka pada awalnya nation (bangsa) dimaknai sebagai "sekelompok orang yang dilahirkan di suatu daerah yang sama" (group of people born ini the same place) (Ritter, 1986). Kata 'nasionalisme' menurut Abbe Barruel untuk pertama kali dipakai di Jerman pada abad ke-15, yang diperuntukan bagi para mahasiswa yang datang dari daerah yang sama atau berbahasa sama, sehingga mereka itu (di kampus yang baru dan daerah baru) tetap menunjukkan cinta mereka terhadap bangsa/suku asal mereka (Ritter, 1986). Nasionalisme pada mulanya terkait dengan rasa cinta sekelompok orang pada bangsa, bahasa dan daerah asal usul semula. Rasa cinta seperti itu dewasa ini disebut semangat patriotisme. Jadi pada mulanya nasionalisme dan patriotisme itu sama maknanya.

Namun sejak revolusi Perancis meletus 1789, pengertian nasionalisme mengalami berbagai pengertian, sebab kondisi yang melatarbelakanginya amat beragam. Antara bangsa yang satu dengan bangsa yang lain. Nasionalisme bukan lagi produk pencerahan Eropa tetapi menjadi label perjuangan dinegara-negara Asia-Afrika yang dijajah bangsa Barat. 
Dari urain di atas kita dapat menarik suatu kesimpulan bahwa nasionalisme merupakan suatu bentuk rasa kebersamaan serta ikatan pesaudaraan dari sekelompok orang yang mendiami suatu wilayah tertentu. Ikatan rasa persaudaraan ini muncul bukan dikarenakan ikatan darah tetapi dikaranekan adanya persaan senasip sepenanggungan karena merasakan atau mengalami hal-hal tertentu yang hampir mirip atau sama.

\section{PEMBAHASAN}

Tidak bisa dipungkiri bahwa dengan memunculkan kembali nilainilai yang kurang diperhatikan dalam PKn diharapkan muncul wawasanwawasan yang mengglobal dari setiap warga Negara tetapi tetap dijiwai oleh rasa nasionalisme yang tinggi. Dengan adanya nasionalisme maka seorang Warga Negara yang memilki wawasan keilmuan yang mampu akan menggunakan semua kemampuannnya secara maksimal demi kebaikan bangsa Indonesia. Hal-hal dasar tersebut yang harus dimiliki oleh setiap warga Negara supaya dapat memunculkan kembali nilai-nilai dasar yang terkandung dalam PKn yang akan bermafaat bagi orang banyak. Nilai-nilai dalam pembelajaran PKn harus dimunculkan serta dimaksimalkan antara lain:

Pertama, pada nilai ketuhanan, manusia Indonesia selain mencintai Tuhan, juga sanggup mencintai sesama tanpa memandang suku, agama, ras, dan golongan. Butir sila Ketuhahan Yang Maha Esa. Hormat dan menghormati serta bekerjasama antara pemeluk agama dan penganutpenganut kepercayaan yang berbeda-beda sehingga terbina kerukunan hidup. Saling menghormati kebebasan menjalankan ibadah sesuai dengan agama dan kepercayaan masing-masing, serta tidak memaksakan suatu agama atau kepercayaannya kepada orang lain. Oleh karena itu kita sebagai warga Negara yang sudah mengenyam pendidikan dan memiliki wawasan lebih di dalam masyarakat bisa memberikan wawasan kepada masyarakat untuk menekankan toleransi antarumat beragama, toleransi sebagai bangsa yang berbhineka, dan merlarang berbagai bentuk kekerasan, dan menekankan adanya pluralitas dan multikulturalisme.

Kedua, pada nilai kemanusiaan, nilai-nilai kemanusiaan seperti saling mencintai sesama manusia, mengembangkan sikap tenggang rasa, tidak semena-mena terhadap orang lain, menjunjung tinggi nilai kemanusiaan, gemar melakukan kegiatan kemanusiaan, dan berani membela kebenaran dan keadilan tidak hanya dipahami tetapi diaplikasikan dalam kehidupan. Nilai-nilai tersebut sangat subur dalam kultur masyarakat Indonesia. Setiap terjadi bencana nasional seperti gempa bumi, erupsi gunung berapi, banjir, tanah longsor, rakyat sigap mengekspresikan nilai Pancasila tersebut secara nyata. Masyarakat membuat dapur umum, membungkusi nasi, mendistribusikan kepada korban tanpa dikomando. Para dokter baik secara perorangan maupun lembaga, bersatu padu menolong mereka yang sakit dan terluka. 
Ketiga, pada nilai persatuan, persatuan disini dimaksudkan bahwa walalupun warga Negara kita bersal dari kalangan yang sangat beraneka ragam. Nilai Persatuan Indonesia mengandung arti ke arah bersatu dalam kebulatan rakyat untuk membina Nasionalisme dalam negara. Nilai Persatuan Indonesia yang demikian ini merupakan suatu proses untuk menuju terwujudnya Nasionalisme. Dengan modal dasar nilai persatuan, semua warga Indonesia baik yang asli maupun keturunan asing dan dari macam-macam suku bangsa dapat menjalin kerjasama yang erat dalam wujud gotongroyong, kebersamaan.

Keempat, Nilai kompetisi, kompetisi disini dimaksudkan guna pengembangan berbagai macam kemampuan yang dimiliki manusia, bukan malah menjadi ajang perdebatan. Semua orang dengan potensi dan kadar kemampuan masing-masing, harus berkompetisi dan berlombalomba dalam melaksanakan kebaikan. Kompetisi penting dijalankan karena melakukan kebaikan tidak seharusnya ditunda-tunda, melainkan harus segera dikerjakan. Sebab kesempatan hidup sangat terbatas, begitu juga kesempatan berbuat baik belum tentu setiap saat kita dapatkan. Kematian bisa datang secara tiba-tiba tanpa diketahui sebabnya. Oleh karena itu, begitu ada kesempatan untuk berbuat baik, janganlah kita tunda-tunda lagi, tetapi harus segera kita kerjakan.

Kelima, nilai keadilan. Keadilan yang dimaksudkan di sini adalah keadilan yang menempatkan sesuatu sesuai dengan porsi/kadarnya. Penempatan sesuatu sesuai dengan kadarnya merupakan sebuah konsep keadilan yang peling adil jika dibandingkan dengan konsep keadilan yang "sama rasa sama rata".

Dari uraian di atas diharapkan akan memunculkan kesadaran yang tinggi serta wawasan yang luas di dalam diri. Dengan kesadaran bahwa kita merasakan adanya kebutuhan memahami masalah global, serta dengan wawasan yang luas kita dapat memilih dan memilah informasi atau nilai mana yang diperlukan dan mana yang tidak, mana yang sesuai dengan nilai budaya kita dan mana yang tidak. Wawasan menggelobal yang dimiliki oleh warga bangsa juga tidak akan mengikis rasa nasionalisme yang mana hal ini bisa pergunakan untuk menyatukan beberapa perbedaan, karena nasionalisme lebih mengutamakan kepentingan umum dari pada kepentingan individu. Jika nasionalisme dapat tertanam pada setiap individu warga Indonesia, maka negara yang bersifat pluralistis ini, artinya negara yang didalamnya terdapat banyak keragaman dan perbedaan, akan menjadi negara yang damai tanpa ada konflik etnik dan konflik kefanatikan terhadap daerahnya masingmasing.Nasionalisme ini akanmampu menangkal perbedaan suku, adatistiadat, ras dan agama.Yang baik harus kita ambil dan yang buruk kita tinggalkan. 


\section{KESIMPULAN}

Dari kajian yang telah dilakukan dapat disimpulkan bahwa ada nilainilai dasar utama yang perlu dikembangkan dalam pendidikan kewarganegaraan untuk membangun wawasan global warga Negara yang dijiwai rasa nasionalisme. Nilai-nilai dasar yang perlu dikembangkan dalam membangun wawasan global dalam konteks Indonesia antara lain ketuhanan, kemanusiaan, persatuan, kerakyatan, keadilan sosial, kompetisi, menghormati orang lain, kemerdekaan dan perdamaian. Nilai-nilai dasar ini penting untuk dikembangkan dalam rangka mengembangkan wawasan global warga Negara yang semnagat didalamnya tetap dijiwai oleh rasa nasionalime agar dapat berperan secara efektif dalam kancah global tanpa meninggalkan jati diri sebagai bangsa Indonesia yang memiliki Pancasila sebagai falsafah dalam kehidupan berbangsa dan bernegara.

\section{DAFTAR PUSTAKA}

Winataputra \&Budimansyah. PKn dalam Perspektif Internasional (Konteks, Teori, dan Profil Pembelajaran).Bandung: Widya Aksara Pers. 2012

Cogan,J. J. Developing the civic society: the role of civic education. Bandung. CICED. 1999

Djahiri, K. Pendidikan nilai moral dalam dimensi pendidikan kewarganegaraan. Bandung: Laboratorium PKn FPIPS UPI. 2006

Ritter, Herry. Dictionary of Concepts in History. New York: Greenwood Press. 1986 